\title{
Firm Performance And Emerging Economies
}

Ramiz Ur Rehman, Xi'an Jiaotong University, China Junrui Zhang, Xi'an Jiaotong University, China

Rizwan Ali, University of Lahore, Pakistan

\begin{abstract}
The study explores the relationship between firm performance, macro-economic variables, and firm size. The analysis was conducted over a period of 12 years, for seven non-financial sectors of Pakistan economy, considering an emerging economy. The analysis was conducted stepwise. First estimation of models considering all co-efficient constant across time and individuals (Sector) was conducted. Secondly, to know the significant difference among the sectors with respect to firm size, return on assets, and earnings per share, we applied LSDV model and kept sectors constant. Lastly, we analyzed the time influence. The results of the study indicate that the size and performance of firms both depend upon financial ratios and macroeconomic variables included in the study. There is significant difference in terms of size and performance between all sectors. There is significant difference in terms of size and performance when measured between 2008 to 2010 and before.
\end{abstract}

Keywords: Firm Performance; Size of the Firm; Non-Financial Sector; Macroeconomic Variables

\section{INTRODUCTION}

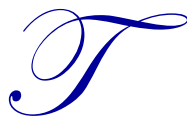

he subject of financial performance, macro-economic variables, and firm size has received significant attention from scholars in the various areas of business. It has also been the primary concern of business practitioners (managers and entrepreneurs) in all types of organizations since financial performance, macro-economic variables, and firm size has implications to organization's health and ultimately its survival. A business entity nowadays, has to be efficient in order to perform and stay in business. Many experts define performance in different ways. Watkins (2007) defined performance as valuable results, accomplishments, or contributions of an individual/team or an organization, regardless of preferred or mandated processes. Enos (2007) defined performance as an achievement of tangible, specific, measurable, worthwhile, and personally meaningful goals. Efficiency measurement is one aspect of a company's performance. Efficiency can be measured with respect to maximization of output, minimization of cost, or maximization of profits. A company is regarded as technically efficient if it is able to obtain maximum outputs from given inputs or minimize inputs used in the production of given outputs. The objective of producers is to avoid waste. Various studies have been carried out to examine the performance of companies. Many studies have used financial ratios such as sales (Wang, 2003), return on assets (Lin et al., 2005; Naser \& Mokhtar, 2004), return on equity (Ponnu \& Ramthandin, 2008), and return on invested capital (Hsu \& Liu, 2008). High performance reflects management effectiveness and efficiency in making use of a company's resources and this in turn contributes to the country's economy at large. Several arguments favor larger firm sizes in attaining higher performance. Large firms are more likely to exploit economies of scale and enjoy higher negotiation power over their clients and suppliers (Serrasqueiro \& Macas Nunes, 2008). In addition, they face less difficulty in getting access to credit for investment, have broader pools of qualified human capital, and may achieve greater strategic diversification (Yang \& Chen 2009). The last 20 years have witnessed privatization programs on a global scale in both developed and developing countries. Different political parties with different ideological backgrounds have strongly pursued the change from state socialism with state-owned enterprises (SOE) to market based capitalism. In most industrialised economies, privatization policies have been promoted on the grounds that it improves the performance of all sectors either in financial or non-financial. 
The question whether firm size matters for financial performance and macro-economic variables effects on firm size and performance is a significant or not. A firm's financial performance can be measured by its profit rate, return on assets, return on equity, financial ratios, and stability of market share. Some of these alternative measures of performance are found related to the firm size; a firm's ability to expand in size can be a reflection of its success as earnings are reinvested and external funding can be easily attracted. This issue of firm size is not of minor importance. An interesting aspect of economic growth is that much of it takes place through the growth in the size of existing organizations. Baumol (1959) hypothesizes that the firm's financial performance increases with the size of the firm. Later on, other researchers observed that the larger the firm size, the higher the returns (Shepherd, 1972). Recently, Punnose (2008) also shows positive relationship between firm size and performance.

Whether firms facing severe environmental growth restrictions perform worse than firms facing softer restrictions, is at least as important. Eliciting answers to this question may allow us to also shed some light on the underlying question between the financial performance and firm size link. An important finding here is that size appears to positively affect firm's financial performance and productivity through economies of scope (Hender-son \& Cockburn, 1996). Abraham (1994) found that the effect was more acute in small and medium sized firms. Another study by Lai, Lim, and Yap (1999) investigated that the impact of firm size on its performance not only at firm level but also on the country's economy. When the market is bullish, smaller firms tend to outperform the larger firms while the larger firms tend to have smaller negative returns during the bearish situation. Even though there is no clear observation that supports smaller firms outperforming the larger firms (bullish), researchers concluded that smaller firms tend to suffer more losses as compared with the larger firms (bearish).

This study will examine the firm's financial performance, macro-economic variables, and firm size, to accomplish this research; we examine the non-financial companies of Pakistan listed in Karachi Stock Exchange since 1999-2010 by Statistics Department State Bank of Pakistan. The non-financial corporate sector is an important segment of a country's economy and a sound, stable, and healthy industrial base is therefore essential for the economic well-being of a country and its populace. Non-financial corporate sector in Pakistan represents a diversified nature of businesses including: textile, sugar, cement, chemical, fuel \& energy, information, communication and transport, paper, paperboard, and products; the macro-economic variables are chosen as control variables.

Distribution of Companies by Economic Groups

\begin{tabular}{|l|c|}
\hline \multicolumn{1}{|c|}{ Economic Groups } & $\mathbf{2 0 1 0}$ \\
\hline 1) Textiles & 164 \\
\hline 2) Sugar & 36 \\
\hline 3) Chemicals, chemical products and Pharmaceuticals & 43 \\
\hline 4) Cement & 21 \\
\hline 5) Fuel \& Energy & 18 \\
\hline 6) Information, Communication \& transport Services & 13 \\
\hline 7) Paper, paperboard and products & 9 \\
\hline Total Companies & $\mathbf{3 0 4}$ \\
\hline
\end{tabular}

\section{REVIEW OF LITERATURE}

In present era, economy of a country is supposed to be symbol of progress and development. How financial and non-financial institutes are performing is of key issue of interest for economists, shareholders, investors, researchers, and policy makers. Following are some studies related to firm financial performance and firm size.

Symeou et al. (2009) tried to identify and understand the relationship between firm size and performance. He aimed to examine that whether the firms whose potential growth is more were performing better. In this study, operationalised in economy size and technical efficiency were taken as a variable for firm growth potential and firm performance respectively. The data was taken for 54 currently working telecommunication companies from an equal number of economies for the years 1990-2007. By keeping the effects of competition, firm hierarchy structure, institutional risk; this study concluded that firm growth is not a significant factor, as both firms operating in small and large economies can operate efficiently. However, growth opportunities are more for firms working in small economies as compared to those who are working in large economies. Naser et al. (2004) selected corporate 
Malaysian companies during the period 1998-2001. The main objective of the study was to explore the factors which influence the financial performance of companies. In order to determine the corporate performance several procedures had adopted, it has been observed the most significant determinant of corporate performance among the companies under the study were ISO. Furthermore, it had found that ROA, EVA, ROS, and Inventory were the factors which were adversely affected by the ISO. Finally, it was revealed that ISO registered companies performed better than the non-ISO registered companies.

Memon et al. (2012) examined the performance of the top fourteen Pakistani manufacturing firms using financial accounting ratios. The study was conducted over a period of five years, from 2006 to 2010. Descriptive statistics of the accounting variables were employed. The study concluded as ENGRO being the largest company by total assets over 3 years $(2006,2007$, and 2008) spent more, made low sales, and had less PBT and ROA than the other thirteen smaller companies. On the other hand, NRL being the fourth largest company by total assets showed the highest sales in five years and lowest expenditures in 2010 as compared to other thirteen listed companies, but it had decreasing PBT and ROA during the period under investigation. The study concluded that few large organizations perform well on large asset grounds and faced huge expanses either firms performance affected by financial expenses. Overall, the study suggested that the low rate of investment of the manufacturing sector caused low rate of growth.

Ammar et al. (2003) said that according to some official contractor of Federated Electrical Contractors, whenever electrical firms grow in size its profitability goes down. In this study, the researchers tried to develop the statistical model to describe the relationship between the firm size and performance in terms of profitability. Economic data were obtained from three sources; i.e., the National Bureau of Economic Research, Bureau of Economic Analysis, and Mortgage Information Service, while financial data was obtained from the FEC group for the period of 1985-1996. In this study, by using backward elimination regression, an indicator variables model with a first-order autoregressive model was developed. For the sake of validation of the model, data for the year 1996 were used, which predicted $76 \%$ of the year 1996 response variable, portability, correctly. For analysis purposes, all electrical firms were divided into three categories according to their size: small, medium, and large. The results of this study revealed that for all three types of electrical firms, there is a significant difference in terms of their profit rate; i.e., as the sale of a company increases more than $\$ 50$ million than their profitability drops.

Velnampy et al. (2010) said that, in present era, due to rapid advancement in technology and strong competition, banking organizations are moving towards achieving a goal of integrated financial services. Now days, it has been observed that in developing countries, such as Sri Lanka, for the sake of organizational developments banking organizations are providing more funds. Since the banking sector plays an important role in economic development and growth of the country, the study sheds light on the effect of firm size on profitability of virtually all branches of Bank of Ceylon (BOC) and Commercial Bank of Ceylon Ltd (CBC). The data is taken from 19972006. Correlation analysis is carried out in this study. The results revealed that firm size and profitability are positively related in the case of Commercial Bank of Ceylon Ltd, but it is not true for the Bank of Ceylon.

Jonsson (2007) said that everybody in the market, especially shareholders and managers desire to grow their businesses and firms and want to become the biggest in their respective industry. It is assumed that large firms have many advantages over their small counterparts, since large firms have a huge scale, scope, specialization, and stronger bargaining power. Hence, bigger firms must be more profitable than smaller firms. In this study the focus has been made on the firms of Iceland and tried to develop the relationship between profitability and size of firms. Data was taken for 250 firms over a period of five years. Mostly, firms were selected from fishing, banking, and civil engineering consulting sectors. It is notable that turnover and total assets were used as the size of the company while return on assets (ROA), return on capital invested (ROIC), and return on equity (ROE) were used as an indicator of profitability. Principal-agent theory, strategic theory, and institutional theory are used to explain and illustrate the result from different aspects.

Ramasamy et al. (2005) had focused on the Malaysian palm oil sector. Their main objective was to find the relationship between the market structure components and different performance measures so that the dynamics and determinants of performance within the Malaysian palm oil companies can be understood. The study explored the effect of firm size and firm ownership on the level of profitability in the palm oil sector. Results revealed that there 
is a negative relationship between the size and performance, while companies in private sectors are found more profitable. This study is very helpful for the Govt. of Malaysia. Chengwen et al. (2012) observed that in the present era, the electronic information industry plays a decisive role in the economic growth of countries. Moreover, the listed companies are supposed to be a central part for the development of electronic information industry. In this study, the researcher selected nineteen domestic listed electronic companies in order to evaluate their performance. The data for selected companies is selected from 2005 to 2010. For analysis purposes, CCR model and window analysis model is used. The analysis of this study showed that the current operation of this industry is stable, but it has a low capacity of endogenous innovation either. Finally, the researcher recommended that it is the need of the day that renovation and novelty is made in structure and technology of firms.

Topak et al. (2011) has examined the Turkish firms and tried to find the relationship between their board size and financial performances. In the emerging market, due to some distinguished qualities such as ownership structure, social cultural, and legal system, Turkey has its value. The data was taken of 122 Turkish firms for the period of 2004-2009. The statistical tool used in this study was the panel data technique to measure the relationship between board size and firm performance. Interestingly, the results of the study were not supporting the results of previous studies and exhibited that board size and firm performance for Turkey are not related to each other; i.e., there is no relationship between them.

Chengwen et al. (2012) analyzed the operating performance of the 19 listed companies in the electronic information industry using panel data from 2005 to 2010. By the vertical and lateral contrast, it helped enterprises understand their own development condition and identify business problems in the operating process such as resources redundancy, low efficiency, and scale improper technology. Results of the study suggested that advanced measures to improve the performance can be taken to promote the sustainable development of the electronic information industry as well.

Majumdar et al. (1997) examined contemporary data for a wide sample of 1020 Indian firms. The study investigated the impacts that size and age of firms have on firm-level productivity and profitability. In India, older firms are found to be more productive and less profitable, whereas larger firms are, conversely, found to be more profitable and less productive. It was concluded that, these performance differences were explained as arising from the market-restricting industrial policies that had been followed in India over the past three decades. The study examined the relationship by using several important variables for firm size and firm performance like, size, sale growth, imports, exports, debt equity ratio, inventory, etc. Dong (2006), using panel data on 165 rural and urban firms from the Nanjing municipality, investigated the pattern and consequences of property rights reform and privatization in the late 1990s. It was found that privatization policies appeared to have targeted the weakest firms in the urban sector, whereas no relationship was found between performance and selection for privatization in the rural sector. For urban firms, the adoption of some degree of private ownership was associated with significant improvements in firm's productivity, performance, and profitability.

McNamara et al. (1995) explained and predicted the base performance of a firm as represented by ROA and macro-economic variables. This study used GDP (CHGGDP), interest rates as embodied in the Treasury note interest rate (IR_TNOTE) as macro-economic variables and aggregate corporate profits after tax (COYPAT), as the performance measure. The results, though preliminary, were promising. Both four variable models incorporating lead-lag relationships have an $\mathrm{R}^{2}$ between .65 and .70 . The study concluded that firm performance is a function of the prior year ROA and macro-economic variables.

Azemi et al. (2009) investigated the effects of macroeconomic factors on GLC share price returns in Malaysia. The performance of the share price was largely attributed to the GLC Transformation Program launched by the government. To examine the impact of the macroeconomic variables on the share price, a simple model was developed based on the Arbitrage Pricing Theory by Ross (1976). The authors examined the short run dynamics and long run equilibrium relationship between G-20 Index and the four selected macroeconomic variables of real output, price level, money supply, and interest rate using monthly data from 1988 to 2008 . The results suggested that the share price and the macroeconomic variables were co-integrated and there was an evidence of long run relationships in the periods under study. 


\section{Objectives of the Study}

The objective on this study is two-fold, one is to determine the financial performance of the non-financial sector by certain financial ratios and macro-economic variables and the second is to explore the impact of certain financial ratios and macro-economic variables on firm size.

\section{Sub Objectives Are:}

- $\quad$ Simultaneous comparison is made of non-financial sector firms in terms of financial performance and firm size on the basis of certain financial ratios and macro-economic variables over the period of 1999-2010.

- $\quad$ To know the difference among the sectors with respect to firm performance and firm size depending upon certain financial ratios and macro-economic variables keeping time as constant.

- $\quad$ To know the difference among the sectors with respect to firm performance and firm size depending upon certain financial ratios and macro-economic variables keeping sectors as constant.

\section{DATA COLLECTION AND MODEL DEVELOPMENT}

\section{Data Collection}

The objectives of this study are twofold. First, we identify firms financial performance and, second, firm size by certain financial ratios and macro-economic variables. To attain these objectives, we used secondary data, a sample of non-financial companies listed in the Karachi Stock Exchange (Department of Statistics State Bank of Pakistan); due to the limitation of data availability we have selected seven sectors out of the twelve; the sectors include: textile, sugar, chemical, cement, fuel \& energy, information, and paper \& board. Data for the years 19992010 were used in this study. The time frame has been chosen in order to capture economics ups and downs, political instability, the impact of financial crunch, energy crises, and natural calamities like earthquake and floods.

\section{Model Development}

Seven measures of firm size have been identified as independent variables and total asset as the dependent variable. These are Current Ration (CR), Return on Equity (ROE), Total Asset Turnover (TATO), Gearing Ratio (GR), and Inventory Turnover Ratio (INVTO). Macro-economic variables are: Gross Domestic Production (GDP) and Interest Rate (IR). The dependent variable is total assets. Six measures of firm performance have been used as independent variables, namely: Current Ration (CR), Gearing Ratio (GR), Inventory (INV), and Total Asset Turnover (TATO). Macro-economic variables are: Gross Domestic Production (GDP) and Interest Rate (IR). The dependent variables are: Return on Asset (ROA) and Earning Per Share (EPS). All these variables are used for the development of estimated models.

\section{Panel Data Analysis}

In panel data, the same cross sectional unit is surveyed over time, other names for panel data combination of time series and cross-sectional data, micro panel data, longitudinal data. By combining time series of crosssection observations, panel data gives "more informative data, more variability, less co-linearity among variables, more degrees of freedom, and more efficiency." By studding the repeated cross section of observations, panel data are better suited to study the dynamics of change. Panel data can better detect and measure effects that simply cannot be observed in pure cross-section or pure time series data. Panel data enables us to study more complicated behavioral models. By making data available for several thousand units, panel data can minimize the bias that might result if we aggregate individuals or firms into broad aggregates. In short, panel data can enrich empirical analysis in ways that may not be possible if we use only cross-section or time series data.

We use the fixed effect model because our observations are not a random sample from a population and also the fixed effect model will be preferable when ' $\mathrm{T}$ ' number of time series data is large and ' $\mathrm{N}$ ' cross sectional units are small. We have $\mathrm{T}=12$ and $\mathrm{N}=7$, so we prefer the fixed effect model case. ${ }^{1}$

\footnotetext{
${ }^{1}$ Gujarati, Damodar n. \& Sangeetha. (2007) Basic Econometrics. McGraw Hill.
} 


\section{Models for Analysis Purpose}

$$
\begin{aligned}
& \operatorname{lnTA} A_{i t}=\beta_{1}+\beta_{2} \mathrm{CR}_{2 \mathrm{it}}+\beta_{3} \mathrm{ROE}_{3 \mathrm{it}}+\beta_{4} \mathrm{TATO}_{4 \mathrm{it}}+\beta_{5} \mathrm{GR}_{5 \mathrm{it}}+\beta_{6} \mathrm{INVTO}_{6 \mathrm{it}}+\beta_{7} \mathrm{GDP}_{7 \mathrm{it}}+\beta_{8} \mathrm{IR}_{8 \mathrm{it}}+\mathrm{U}_{\mathrm{it}} \\
& \mathrm{ROA}_{\mathrm{it}}=\beta_{1}+\beta_{2} \mathrm{CR}_{2 \mathrm{it}}+\beta_{3} \mathrm{GR}_{3 \mathrm{it}}+\beta_{4} \mathrm{INV}_{4 \mathrm{it}}+\beta_{5} \mathrm{TATO}_{5 \mathrm{it}}+\beta_{6} \mathrm{GDP}_{6 \mathrm{it}}+\beta_{7} \mathrm{IR}_{7 \mathrm{it}}+\mathrm{U}_{\mathrm{it}} \\
& \mathrm{EPS}_{\mathrm{it}}=\beta_{1}+\beta_{2} \mathrm{CR}_{2 \mathrm{it}}+\beta_{3} \mathrm{GR}_{3 \mathrm{it}}+\beta_{4} \mathrm{INV}_{4 \mathrm{it}}+\beta_{5} \mathrm{TATO}_{5 \mathrm{it}}+\beta_{7} \mathrm{GDP}_{7 \mathrm{it}}+\beta_{8} \mathrm{IR}_{8 \mathrm{it}}+\mathrm{U}_{\mathrm{it}}
\end{aligned}
$$

Where,

$\mathrm{i}=1,2,3,4,5,6,7$ (No. of sectors)

$\mathrm{t}=1,2,3,4,5,6,7,8,9,10,11,12$ (No. of years)

Expected Signs

\begin{tabular}{|l|l|c|c|c|c|}
\hline \multicolumn{2}{|c|}{ Model-I } & \multicolumn{2}{c|}{ Model-II } & \multicolumn{2}{c|}{ Model-III } \\
\hline \multicolumn{1}{|c|}{ Variables } & ES & Variables & ES & Variables & ES \\
\hline CR & $+\mathrm{ve}$ & CR & $+\mathrm{ve}$ & CR & $+\mathrm{ve}$ \\
ROE & $+\mathrm{ve}$ & GR & $-\mathrm{ve}$ & GR & $-\mathrm{ve}$ \\
TATO & $+\mathrm{ve}$ & INV & $+\mathrm{ve}$ & INV & $+\mathrm{ve}$ \\
GR & $-\mathrm{ve}$ & TATO & $-\mathrm{ve}$ & TATO & $-\mathrm{ve}$ \\
INVTO & $+\mathrm{ve}$ & GDP & $+\mathrm{ve}$ & GDP & $+\mathrm{ve}$ \\
GDP & $+\mathrm{ve}$ & IR & $-\mathrm{ve}$ & IR & $-\mathrm{ve}$ \\
IR & $-\mathrm{ve}$ & & & & \\
\hline
\end{tabular}

Assumptions of Models 1, 2, \& 3 have several possibilities.

1. All co-efficient constant across time and individuals.

2. Slope co-efficient constant but intercept varies across individuals.

3. The fixed effects or Least Square Dummy Variables (LSDV) regression model.

4. Slope co-efficient constant but intercept varies over individual as well as time.

5. All co-efficient vary across individuals.

Estimation of Models Considering All co-Efficient Constant Across Time and Individuals (Sector).

Estimation of Models 1, 2, \& 3 by Ordinary Least Square regression done using STATA software gives following results.

\section{Estimation of Model 1}

Table I: Dependant Variable: $\ln$ TA

\begin{tabular}{|l|c|c|c|c|}
\hline \multicolumn{1}{|c|}{ Variables } & Coefficients & SE & t-stat & p-value \\
\hline Intercept & -63.3041 & 29.61 & -2.14 & $0.02^{* *}$ \\
\hline CR & +0.11 & 0.02 & 8.02 & $0.00^{* * *}$ \\
\hline ROE & +0.30 & 0.05 & 6.15 & $0.00^{* * *}$ \\
\hline TATO & +0.25 & 0.03 & 8.33 & $0.00^{* * *}$ \\
\hline GR & -0.10 & 0.01 & -10.00 & $0.00 * * *$ \\
\hline INVTO & +0.65 & 0.07 & 9.29 & $0.00^{* * *}$ \\
\hline GDP & +0.59 & 0.01 & 4.92 & $0.00^{* * *}$ \\
\hline IR & -0.09 & 0.01 & -9 & $0.00^{* * *}$ \\
\hline
\end{tabular}

$\mathrm{R}^{2}=0.76, \mathrm{dw}=2.22, \mathrm{n}=84, \mathrm{df}=76$. All the explanatory variables are significant and the explanatory power of the model-1 is $76 \%$ and $\mathrm{dw}$ stats indicates there is no auto-correlation problem. *** Highly significant at $1 \%$, ** significant at $5 \%$, * significant at $10 \%$. 


\section{Estimation of Model-2}

Table II: Dependant Variable: ROA

\begin{tabular}{|l|c|c|c|}
\hline \multicolumn{1}{|c|}{ Variables } & Coefficients & SE & p-value \\
\hline Intercept & -59.65 & 14.25 & -4.18 \\
\hline CR & +0.76 & 0.04 & 19.00 \\
\hline GR & -0.50 & 0.02 & -25 \\
\hline INV & +0.68 & 0.34 & $0.00 * * *$ \\
\hline TATO & +0.14 & 0.10 & $0.00 * * *$ \\
\hline GDP & +0.57 & 0.25 & $0.02 * *$ \\
\hline IR & -0.79 & 0.20 & $0.08 *$ \\
\hline
\end{tabular}

$\mathrm{R}^{2}=0.70$, d.w $=2.10, \mathrm{n}=84, \mathrm{df}=77$. All the explanatory variables are significant and the explanatory power of the model-2 is $70 \%$ and dw stats indicates there is no auto-correlation problem. *** Highly significant at $1 \%, * *$ significant at $5 \%$, $*$ significant at $10 \%$.

The explanatory variables CR, GR, IR found to be highly significant and INV and GDP are significant at $5 \%$ and TATO significant at $10 \%$ and the explanatory power of the model- 2 is $70 \%$ and dw stats indicates there is no auto-correlation problem.

\section{Estimation of Model-3}

Table III: Dependant Variable: EPS

\begin{tabular}{|l|c|c|c|c|}
\hline \multicolumn{1}{|c|}{ Variables } & Coefficients & SE & t-stat & p-value \\
\hline Intercept & 53.36 & 35.25 & 1.51 & $0.07 *$ \\
\hline CR & +0.79 & 0.04 & 19.00 & $0.00^{* * *}$ \\
\hline GR & -0.97 & 0.05 & -25 & $0.00^{* * *}$ \\
\hline INV & +0.65 & 0.07 & 2.00 & $0.00^{* * *}$ \\
\hline TATO & +0.153 & 0.10 & 1.4 & $0.00^{* * *}$ \\
\hline GDP & +0.60 & 0.10 & 2.28 & $0.00^{* * *}$ \\
\hline IR & -0.10 & 0.02 & -3.95 & $0.00^{* * *}$ \\
\hline
\end{tabular}

$\mathrm{R}^{2}=0.69, \mathrm{~d} . \mathrm{w}=2.65, \mathrm{n}=84, \mathrm{df}=77$. All the explanatory variables are significant and the explanatory power of the model-3 is $69 \%$ and dw stats indicates there is no auto-correlation problem. *** Highly significant at $1 \%$, ** significant at $5 \%$, * significant at $10 \%$.

All the explanatory variables are significant and the explanatory power of the model-3 is $69 \%$ and dw stats indicates there is no auto-correlation problem.

\section{Fixed Effect Model or Least Square Dummy Variable Regression Model (LSDV) as Time Constant:}

To know the significant difference among the sectors with respect to FS, ROA, and EPS we apply the LSDV model. As there are 7 sectors, we will introduce six dummy variables; i.e., D1, D2, D3, D4, D5, and D6, taking Textile Sector as base line category, the dummy scheme will be as follows:

- $\quad$ D1: 1 for cement, 0 for others

- $\quad$ D2: 1 for chemical, 0 for others

- $\quad$ D3: 1 for fuel \& energy, 0 for others

- D4: 1 for information, 0 for others

- $\quad$ D5: 1 for papers, 0 for others

- $\quad$ D6: 1 for sugar, 0 for others

$\ln$ A Ait $=\alpha 0+\sum 6 \mathrm{i}=1 \alpha \mathrm{jDjit}+\beta 2 \mathrm{CR} 2 \mathrm{it}+\beta 3 \mathrm{ROE} 3 \mathrm{it}+\beta 4 \mathrm{TATO} 4 \mathrm{it}+\beta 5 \mathrm{GR} 5 \mathrm{it}+\beta 6 \mathrm{INVTO} 6 \mathrm{it}+$

$\beta 7$ GDP7it $+\beta 8$ IR8it + Uit

ROAit $=\alpha 0+\sum 6 \mathrm{i}=1 \alpha \mathrm{j}$ jit $+\beta 2 \mathrm{CR} 2 \mathrm{it}+\beta 3 \mathrm{GR} 3 \mathrm{it}+\beta 4 \mathrm{INV} 4 \mathrm{it}+\beta 5 \mathrm{TATO} 5 \mathrm{it}+\beta 6 \mathrm{GDP} 6 \mathrm{it}+\beta 7 \mathrm{IR} 7 \mathrm{it}+\mathrm{Uit}$

EPSit $=\alpha 0+\sum 6 \mathrm{i}=1 \alpha \mathrm{jDjit}+\beta 2 \mathrm{CR} 2 \mathrm{it}+\beta 3 \mathrm{GR} 3 \mathrm{it}+\beta 4 \mathrm{INV} 4 \mathrm{it}+\beta 5 \mathrm{TATO} 5 \mathrm{it}+\beta 6 \mathrm{GDP} 6 \mathrm{it}+\beta 7 \mathrm{IR} 7 \mathrm{it}+\mathrm{Uit}$

Estimation of LSDV Models 4, 5, \& 6 by Ordinary Least Square regression done using STATA software gives following results. 
Table IV: Dependant Variable: InTA

\begin{tabular}{|l|c|c|c|c|}
\hline \multicolumn{1}{|c|}{ Variables } & Coefficients & SE & t-stat & p-value \\
\hline Intercept & 138006.9 & 5600 & 24.9 & $0.00^{* * *}$ \\
\hline $\mathrm{D}_{1}$ & -0.05 & 0.02 & -2.5 & $0.01^{* *}$ \\
\hline $\mathrm{D}_{2}$ & -0.32 & 0.16 & -2 & $0.02^{* *}$ \\
\hline $\mathrm{D}_{3}$ & -0.14 & 0.10 & -1.4 & $0.08^{*}$ \\
\hline $\mathrm{D}_{4}$ & 0.12 & 0.05 & 2.4 & $0.01^{* *}$ \\
\hline $\mathrm{D}_{5}$ & 0.10 & 0.04 & 2.5 & $0.01^{* *}$ \\
\hline $\mathrm{D}_{6}$ & -0.17 & 0.06 & -2.83 & $0.00^{* * *}$ \\
\hline CR & 1.08 & 0.49 & 2.20 & $0.02^{* *}$ \\
\hline ROE & 16.00 & 7.25 & 2.21 & $0.02^{* *}$ \\
\hline TATO & 1.35 & 0.35 & 3.86 & $0.00^{* * *}$ \\
\hline GR & 0.36 & 0.20 & 1.8 & $0.04^{* *}$ \\
\hline INVTO & 0.65 & 0.25 & 2.6 & $0.01^{* *}$ \\
\hline GDP & 0.05 & 0.02 & 2.5 & $0.01^{* *}$ \\
\hline IR & 0.16 & 0.10 & 1.6 & $0.06^{*}$ \\
\hline
\end{tabular}

$\mathrm{R}^{2}=0.90, \mathrm{~d} . \mathrm{w}=2.40, \mathrm{n}=84, \mathrm{df}=71$. All the explanatory variables are significant and the explanatory power of the model is $90 \%$ and dw stats indicates there is no auto-correlation problem. *** Highly significant at $1 \%, * *$ significant at $5 \%$, * significant at $10 \%$.

The p-value of D6 suggests that there is a highly significant difference between total assets of textile and sugar sector. The p-values of D2, D4, \& D5 suggest there is a significant difference between the assets of chemical, information \& paper with textile sector at 5\% level of significance. The p-value of D3 indicates that there is a significant difference between the assets of fuel \& energy with the textile sector at $10 \%$ level of significant. The explanatory variable TATO found to be highly significant and CR, ROE, GR, INVTO, and GDP are significant at $5 \%$ and IR significant at $10 \%$ and the explanatory power of the model- 4 is $90 \%$ and dw stats indicates there is no auto-correlation problem.

Table-V: Dependant Variable: ROA

\begin{tabular}{|l|c|c|c|c|}
\hline \multicolumn{1}{|c|}{ Variables } & Coefficients & SE & t-stat & p-value \\
\hline Intercept & 126005.7 & 5450 & 23.12 & $0.08^{*}$ \\
\hline $\mathrm{D}_{1}$ & -10.75 & 2.58 & -4.17 & $0.00^{* * *}$ \\
\hline $\mathrm{D}_{2}$ & -7.82 & 2.50 & -3.13 & $0.00^{* * *}$ \\
\hline $\mathrm{D}_{3}$ & -7.66 & 2.00 & -3.83 & $0.00^{* * *}$ \\
\hline $\mathrm{D}_{4}$ & -11.08 & 2.85 & -3.89 & $0.00^{* * *}$ \\
\hline $\mathrm{D}_{5}$ & 0.64 & 1.58 & 0.41 & $0.08^{*}$ \\
\hline $\mathrm{D}_{6}$ & -1.28 & 3.00 & -0.43 & $0.06^{*}$ \\
\hline CR & +0.40 & 0.15 & 2.65 & $0.01^{* *}$ \\
\hline GR & -0.42 & 0.19 & 2.21 & $0.03^{* *}$ \\
\hline INV & +4.95 & 1.20 & 4.12 & $0.00^{* * *}$ \\
\hline TATO & +1.20 & 0.65 & 1.84 & $0.07^{*}$ \\
\hline GDP & +3.13 & 0.76 & 4.12 & $0.00^{* * *}$ \\
\hline IR & -2.68 & 1.40 & 1.91 & $0.06^{*}$ \\
\hline
\end{tabular}

$\mathrm{R}^{2}=90 \%, \mathrm{~d} \cdot \mathrm{w}=2.48, \mathrm{n}=84, \mathrm{df}=72$. All the explanatory variables are significant and the explanatory power of the model is $90 \%$ and dw stats indicates there is no auto-correlation problem. *** Highly significant at $1 \%$, ** significant at $5 \%$, * significant at $10 \%$.

The p-value of D1, D2, D3, and D4 suggest that there is a highly significant difference between ROA of textile and cement, chemical, fuel \& energy, and information sectors. The p-values of D5 \& D6 suggest there is a significant difference between the ROA of paper and sugar with textile sector at $10 \%$ level of significance. The explanatory variable INV \& GDP found to be highly significant and CR and GR are significant at 5\% and TATO and IR significant at $10 \%$ and the explanatory power of the model-5 is $90 \%$ and dw stats indicates there is no autocorrelation problem. 
Table VI: Dependant Variable: EPS

\begin{tabular}{|l|c|c|c|c|}
\hline \multicolumn{1}{|c|}{ Variables } & Coefficients & SE & t-stat & p-value \\
\hline Intercept & 130606.7 & 5360 & 24.36 & $0.04^{* *}$ \\
\hline $\mathrm{D}_{1}$ & -10.75 & 2.58 & -4.17 & $0.00^{* * *}$ \\
\hline $\mathrm{D}_{2}$ & -7.82 & 2.50 & -3.13 & $0.00^{* * *}$ \\
\hline $\mathrm{D}_{3}$ & -7.66 & 2.00 & -3.83 & $0.00^{* * *}$ \\
\hline $\mathrm{D}_{4}$ & -11.08 & 2.85 & -3.89 & $0.00^{* * *}$ \\
\hline $\mathrm{D}_{5}$ & 0.64 & 1.58 & 0.41 & $0.08^{*}$ \\
\hline $\mathrm{D}_{6}$ & -1.28 & 3.00 & -0.43 & $0.06^{*}$ \\
\hline $\mathrm{CR}$ & 3.31 & 1.25 & 2.65 & $0.01^{* *}$ \\
\hline GR & -3.65 & 1.65 & -2.21 & $0.03^{* *}$ \\
\hline INV & 4.12 & 1.00 & 4.12 & $0.00^{* * *}$ \\
\hline TATO & 3.29 & 1.79 & 1.84 & $0.07^{*}$ \\
\hline GDP & 9.57 & 2.32 & 4.12 & $0.00^{* * *}$ \\
\hline IR & -5.28 & 2.76 & -1.91 & $0.06^{*}$ \\
\hline
\end{tabular}

$\mathrm{R}^{2}=88 \%$, d.w $=2.17, \mathrm{n}=84, \mathrm{df}=72$. All the explanatory variables are significant and the explanatory power of the model is $88 \%$ and dw stats indicates there is no auto-correlation problem. $* * *$ Highly significant at $1 \%$, ** significant at $5 \%$, * significant at $10 \%$.

The p-value of D1, D2, D3, and D4 suggest that there is a highly significant difference between EPS of textile and cement, chemical, fuel \& energy, and information sectors. The p-values of D5 \& D6 suggest there is a significant difference between the EPS of paper and sugar with the textile sector at $10 \%$ level of significance. The explanatory variable INV \& GDP found to be highly significant and CR and GR are significant at 5\% and TATO and IR significant at $10 \%$ and the explanatory power of the model- 6 is $88 \%$ and dw stats indicates there is no autocorrelation problem.

\section{Fixed Effect Model or Least Square Dummy Variable Regression Model (LSDV) as Sector Constant:}

To know about the time impact, as we have 12 years data, so, we introduce 11 Dummies taking 1999 as base year. The Models are:

$\operatorname{lnTAit}=\alpha 0+\sum 11 \mathrm{i}=1 \alpha \mathrm{j} \mathrm{Djit}+\beta 2 \mathrm{CR} 2 \mathrm{it}+\beta 3 \mathrm{ROE} 3 \mathrm{it}+\beta 4 \mathrm{TATO} 4 \mathrm{it}+\beta 5 \mathrm{GR} 5 \mathrm{it}+\beta 6 \mathrm{INVTO}$ it

$+\beta 7$ GDP7it $+\beta 8$ IR8it + Uit

ROAit $=\alpha 0+\sum 11 \mathrm{i}=1 \alpha \mathrm{j}$ Djit $+\beta 2 \mathrm{CR} 2 \mathrm{it}+\beta 3 \mathrm{GR} 3 \mathrm{it}+\beta 4 \mathrm{INV} 4 \mathrm{it}+\beta 5$ TATO5it $+\beta 6 \mathrm{GDP} 6 \mathrm{it}+\beta 7 \mathrm{IR} 7 \mathrm{it}+\mathrm{Uit}$

EPSit $=\alpha 0+\sum 11 \mathrm{i}=1 \alpha j \mathrm{Djit}+\beta 2 \mathrm{CR} 2 \mathrm{it}+\beta 3 \mathrm{GR} 3 \mathrm{it}+\beta 4 \mathrm{INV} 4 \mathrm{it}+\beta 5 \mathrm{TATO}$ it $+\beta 6 \mathrm{GDP} 6 \mathrm{it}+\beta 7 \mathrm{IR} 7 \mathrm{it}+\mathrm{Uit}$

To know the significant difference among the time with respect to FS, ROA, \& EPS. As there are 12 years so, we will introduce eleven dummy variables; i.e., D1, D2, D3, D4, D5, D6, D7, D8, D9, D10, D11, taking 1999 year as base line category, the dummy scheme will be as follows:

- $\quad$ D1: 1 for 2000, 0 for others

- $\quad$ D2: 1 for 2001, 0 for others

- $\quad$ D3: 1 for 2002, 0 for others

- D4: 1 for 2003, 0 for others

- $\quad$ D5: 1 for 2004, 0 for others

- D6: 1 for 2005, 0 for others

- $\quad$ D7: 1 for 2006, 0 for others

- $\quad$ D8: 1 for 2007, 0 for others

- $\quad$ D9: 1 for 2008, 0 for others

- D10: 1 for 2009, 0 for others

- D11: 1 for 2010, 0 for others 
Table VII: Dependant Variable: $\ln$ TA

\begin{tabular}{|l|c|c|c|c|}
\hline \multicolumn{1}{|c|}{ Variables } & Coefficients & SE & t-stat & p-value \\
\hline Intercept & 814.45 & 187.35 & 4.34 & $0.07^{*}$ \\
\hline $\mathrm{D}_{01}$ & -3.61 & 91.92 & 0.04 & 0.97 \\
\hline $\mathrm{D}_{02}$ & -11.08 & 91.90 & 0.12 & 0.91 \\
\hline $\mathrm{D}_{03}$ & -13.22 & 91.89 & 0.14 & 0.89 \\
\hline $\mathrm{D}_{04}$ & -19.54 & 91.85 & 0.21 & 0.84 \\
\hline $\mathrm{D}_{05}$ & -54.52 & 91.37 & 0.60 & 0.56 \\
\hline $\mathrm{D}_{06}$ & -73.82 & 90.90 & 0.81 & 0.43 \\
\hline $\mathrm{D}_{07}$ & -109.77 & 89.68 & 1.22 & 0.24 \\
\hline $\mathrm{D}_{08}$ & -148.09 & 87.87 & 1.69 & 0.12 \\
\hline $\mathrm{D}_{09}$ & -189.88 & 85.35 & 2.22 & $0.05^{*}$ \\
\hline $\mathrm{D}_{10}$ & -278.17 & 78.36 & 3.55 & $0.00^{* * *}$ \\
\hline $\mathrm{D}_{11}$ & -313.69 & 75.03 & 4.18 & $0.00^{* * *}$ \\
\hline CR & +0.09 & 0.02 & 4.50 & $0.00^{* * *}$ \\
\hline ROE & +0.25 & 0.05 & 5.00 & $0.00^{* * *}$ \\
\hline TATO & +0.20 & 0.03 & 6.67 & $0.00^{* * *}$ \\
\hline GR & -0.09 & 0.01 & -9.00 & $0.00^{* * *}$ \\
\hline INVTO & +0.55 & 0.07 & 7.86 & $0.00^{* * *}$ \\
\hline GDP & +0.50 & 0.01 & 50.00 & $0.00^{* * *}$ \\
\hline IR & -0.07 & 0.01 & -7.00 & $0.00^{* * *}$ \\
\hline
\end{tabular}

$\mathrm{R}^{2}=0.93, \mathrm{~d} . \mathrm{w}=2.10, \mathrm{n}=84, \mathrm{df}=66$. All the explanatory variables are significant and the explanatory power of the model is $93 \%$ and dw stats indicates there is no auto-correlation problem. $* * *$ Highly significant at $1 \%$, ** significant at $5 \%$, * significant at $10 \%$.

The p-value of D10 and D11 suggest that there is a highly significant difference between FS of 1999 and 2009 and 2010. The explanatory variable CR, ROE, TATO, GR, INVTO, GDP, and IR found to be highly significant and the explanatory power of the model-7 is $91 \%$ and $\mathrm{dw}$ stats indicates there is no auto-correlation problem.

Table VIII: Dependent Variable: ROA

\begin{tabular}{|l|c|c|c|c|}
\hline \multicolumn{1}{|c|}{ Variables } & Coefficients & SE & t-stat & p-value \\
\hline Intercept & 791.31 & 191.05 & 4.14 & $0.01^{* *}$ \\
\hline $\mathrm{D}_{01}$ & -3.61 & 28.61 & 0.13 & 0.90 \\
\hline $\mathrm{D}_{02}$ & -11.08 & 62.58 & 0.18 & 0.86 \\
\hline $\mathrm{D}_{03}$ & -13.22 & 46.70 & 0.28 & 0.78 \\
\hline $\mathrm{D}_{04}$ & -19.54 & 78.88 & 0.25 & 0.81 \\
\hline $\mathrm{D}_{05}$ & -54.52 & 121.69 & 0.45 & 0.66 \\
\hline $\mathrm{D}_{06}$ & -73.82 & 77.22 & 0.96 & 0.34 \\
\hline $\mathrm{D}_{07}$ & -109.77 & 85.64 & 1.28 & 0.20 \\
\hline $\mathrm{D}_{08}$ & -148.09 & 89.24 & 1.66 & 0.10 \\
\hline $\mathrm{D}_{09}$ & -189.88 & 90.91 & 2.09 & 0.04 \\
\hline $\mathrm{D}_{10}$ & -278.17 & 80.75 & 3.44 & $0.00^{* * *}$ \\
\hline $\mathrm{D}_{11}$ & -270.15 & 81.60 & 3.21 & $0.00^{* * *}$ \\
\hline CR & -313.69 & 98.78 & 3.18 & $0.00^{* * *}$ \\
\hline GR & 0.01 & 0.09 & 0.14 & $0.05^{* *}$ \\
\hline INV & 177.37 & 261.52 & 0.68 & $0.07^{*}$ \\
\hline TATO & 11.76 & 2.84 & 4.14 & $0.00^{* * *}$ \\
\hline GDP & 0.06 & 0.03 & -2.10 & $0.04^{* *}$ \\
\hline IR & 0.05 & 0.02 & 2.65 & $0.01^{* * *}$ \\
\hline
\end{tabular}

$\mathrm{R}^{2}=0.90, \mathrm{~d} . \mathrm{w}=2.60, \mathrm{n}=84, \mathrm{df}=67$. All the explanatory variables are significant and the explanatory power of the model is $90 \%$ and dw stats indicates there is no auto-correlation problem. $* * *$ Highly significant at $1 \%$, ** significant at $5 \%$, * significant at $10 \%$.

The p-value of D10 and D11 suggest that there is a highly significant difference between ROA of 1999 and 2009 and 2010. The p-value of D9 suggests that there is a significant difference at 5\%, D8 suggest that there is significant difference at $10 \%$. The explanatory variable CR and TATO found to be highly significant, the explanatory variable IR, GDP, and GR found to be significant at 5\%, the explanatory variable INV found to be 
significant at $10 \%$ and the explanatory power of the model-8 is $93 \%$ and $\mathrm{dw}$ stats indicates there is no autocorrelation problem.

\begin{tabular}{|c|c|c|c|c|}
\hline Variables & Coefficients & SE & t-stat & p-value \\
\hline Intercept & 752.52 & 191.05 & 3.94 & 0.0002 \\
\hline $\mathrm{D}_{01}$ & -3.61 & 286.83 & 0.01 & 0.99 \\
\hline $\mathrm{D}_{02}$ & -11.08 & 26.75 & 0.41 & 0.68 \\
\hline $\mathrm{D}_{03}$ & -13.22 & 45.03 & 0.29 & 0.77 \\
\hline $\mathrm{D}_{04}$ & -19.54 & 76.84 & 0.25 & 0.80 \\
\hline$D_{05}$ & -54.52 & 103.46 & 0.53 & 0.60 \\
\hline $\mathrm{D}_{06}$ & -73.82 & 70.67 & 1.04 & 0.30 \\
\hline $\mathrm{D}_{07}$ & -109.77 & 86.71 & 1.27 & 0.21 \\
\hline $\mathrm{D}_{08}$ & -148.09 & 86.07 & 1.72 & 0.09 \\
\hline $\mathrm{D}_{09}$ & -189.88 & 80.04 & 2.37 & 0.02 \\
\hline $\mathrm{D}_{10}$ & -278.17 & 103.50 & 2.69 & $0.01^{* * *}$ \\
\hline $\mathrm{D}_{11}$ & 271.51 & 98.25 & 2.51 & $0.01^{* *}$ \\
\hline $\mathrm{CR}$ & -313.69 & 92.85 & 3.38 & $0.00 * * *$ \\
\hline GR & 0.00 & 0.09 & 0.03 & $0.06^{*}$ \\
\hline INV & 141.61 & 261.52 & 0.54 & $0.06^{*}$ \\
\hline TATO & 11.19 & 2.84 & 3.94 & $0.00 * * *$ \\
\hline GDP & 0.06 & 0.03 & -2.08 & $0.04 * *$ \\
\hline IR & 0.07 & 0.02 & 3.44 & $0.00 * * *$ \\
\hline
\end{tabular}

$\mathrm{R}^{2}=0.92$, d.w $=2.50, \mathrm{n}=84, \mathrm{df}=67$. All the explanatory variables are significant and the explanatory power of the model is $92 \%$ and dw stats indicates there is no auto-correlation problem. *** Highly significant at $1 \%, * *$ significant at $5 \%$, $*$ significant at $10 \%$.

The p-value of D9, D10, and D11 suggest that there is a significant difference between EPS of 1999 and 2008,2009 , and 2010. P-value of D8 suggests that there is a significant difference at $10 \%$. The explanatory variable CR, TATO, and IR was found to be highly significant, explanatory variable GDP was found to be significant at 5\%, GR and INV were found to be significant at $10 \%$, and the explanatory power of the model-7 is $91 \%$ and dw stats indicates there is no auto-correlation problem.

\section{DISCUSSION AND CONCLUSION}

Our analysis was performed in three stages. Our study relates financial rations, macroeconomic variables to firm size. For this purpose panel data analysis has been applied. Further, we apply fixed effect model because our observations are not random. Our first model captures the factors effecting firm size. Similarly, second and third models relate firms performance to financial ratios and macro-economic variables. In the first stage, the estimation of the models considering all the coefficients constant across time and individuals (sectors) has been done. Ordinary Least Square regression has been applied using STATA software to serve our purpose.

After applying the models, we find all the explanatory variables of Models 1 and 3 to be significant. CR, GR, and IR are found to be highly significant and INV and GDP are significant at 5\% whereas TATO is significant at $10 \%$ for Model 2. The explanatory powers of Models 1, 2, and 3 are $76 \%, 70 \%$, and $69 \%$ respectively. Further, $\mathrm{dw}$ stats indicates that there is no autocorrelation problem in all models. The results show that the size and performance of firms both depend upon financial ratios and macro-economic variables included in the study. The models fully explain the phenomenon.

In the second stage, we apply Fixed Effect Model or Least Square Dummy Variable Regression Model (LSDV) to know the significant difference among the sectors with respect to FS, ROA, and EPS we apply LSDV model. As there are 7 sectors, we introduce six dummy variables; i.e., D1, D2, D3, D4, D5, D6, and taking the textile sector as the base line category. Estimation of LSDV Models 4, 5, and 6 by Ordinary Least Square regression has been done using STATA software gives following results.

The p-values of Models 4, 5, and 6 suggest that there is a highly significant difference between total assets of the textile and sugar sector, a significant difference between the assets of chemical, information \& paper with the 
textile sector at $5 \%$ level of significance, a significant difference between the assets of fuel \& energy with the textile sector at $10 \%$ level of significant, highly significant difference between ROA of textile and cement, chemical, fuel $\&$ energy, and information sectors, a significant difference between the ROA of paper and sugar with textile sector at $10 \%$ level of significance, a highly significant difference between EPS of textile and cement, chemical, fuel \& energy, and information sectors, and a significant difference between the EPS of paper and sugar with the textile sector at $10 \%$ level of significance.

The explanatory variable TATO found to be highly significant and CR, ROE, GR, INVTO, and GDP are significant at 5\% and IR significant at $10 \%$ and the explanatory power of the Model- 4 is $90 \%$. The explanatory variable INV \& GDP are found to be highly significant and CR and GR are significant at 5\% and TATO and IR significant at $10 \%$ and the explanatory power of the Model-5 is $90 \%$. The explanatory variable INV \& GDP found to be highly significant and CR and GR are significant at 5\% and TATO and IR significant at 10\% and the explanatory power of the Model- 6 is $88 \%$ and dw stats indicates there is no auto-correlation problem in all three models. These results show that there is significant difference in terms of size and performance between all sectors.

In the third stage, we again apply Fixed Effect Model or Least Square Dummy Variable Regression Model (LSDV) to know the time impact, as we have 12 years data, so, we introduce 11 Dummies taking 1999 as base year. The derived as follows: The p-values of the Models 7, 8, and 9 show significant difference between FS of 1999, 2008, 2009, and 2010; a highly significant difference between ROA of 1999, 2008, 2009, and 2010; a significant difference at 5\%; and a significant difference between EPS of 1999, 2008, 2009, and 2010.

The explanatory variable CR, ROE, TATO, GR, INVTO, GDP, and IR found to be highly significant and the explanatory power of Model-7 is $91 \%$. The explanatory variable CR and TATO found to be highly significant, the explanatory variable IR, GDP, and GR found to be significant at 5\%, the explanatory variable INV found to be significant at $10 \%$, and the explanatory power of Model-8 is $93 \%$. The explanatory variable CR, TATO, and IR found to be highly significant, explanatory variable GDP found to be significant at 5\%, GR and INV found to be significant at $10 \%$, and the explanatory power of Model-9 is $92 \%$ and dw stats indicates there is no auto-correlation problem. The results show that there is significant difference in terms of size and performance when measured over the time especially between $2008-2010$ and the prior period.

However, our study brings the different picture. Though the Musharraf was considered to be conducive to the economic policies, they paid off late. Our descriptive and analytical analysis depicts the same. We have seen firm size and performance variables be disturbed. Although the size of selected sectors is increased during 2008-10, this increase did not lead to increased performance thereby it is not contributing to the overall GDP of country. This is very evident from the recent history.

The underlying reasons for this trend is as follows. The country faced multiple adverse shocks of commodity and oil prices internationally and the fallout of the global financial crisis. In the era of 2008 commodity, precious metals and oil prices (round \$150) per barrel which directly affects the performance of all sectors and increases the operating cost of production. The poor performance of selected sectors has something to do with the performance of overall economy which was understandable in the context of acute energy shortages and constrained international demand for Pakistan's manufactured exports. Pakistan's macroeconomic environment was affected by intensification of war on terror and deepening of the global financial crisis which penetrated into domestic economy through the route of substantial decline in Pakistan's exports and a visible slowdown in foreign direct inflows.

Pakistan's economy lost significant momentum especially during 2008-10. Finally, Pakistan is rich in human and material resources but poor governance of the country has impeded the process of exploitation of these resources. Some of the essential ingredients of good governance that are lacking in Pakistan are rule of law, effective institutional checks and balances, transparency and accountability, safety and security, well defined and well-functioning federation, strong state institutions, and a coherent long term national economic agenda that, along with foreign policy, is jointly approved by the major political parties, and implemented by all governments through a transparent institutional framework, Good governance in all these dimensions is a prerequisite to get out of the present economic crisis. 


\section{ACKNOWLEDGEMENT}

This research was supported by National Science Foundation of China (Grant No. 71172186).

\section{AUTHOR INFORMATION}

Ramiz ur Rehman is currently pursuing his PhD in Financial Management from the School of Management, Xi'an Jiaotong University, Xi'an, Shaanxi, PR China. He has more than ten years of teaching and research experience at the university level. He has also published several research articles in reputable journals; e.g., Journal of Finance Issues, Journal of Leadership, Accountability and Ethics, and Pakistan Development Review. He is also serving as an Assistant Professor of finance at Lahore Business School, The University of Lahore. E-mail: ramiz_rehman@hotmail.com (Corresponding Author)

Dr. Junrui Zhang is a professor of accounting in the School of Management at Xi'an Jiaotong University. His main research interests include corporate governance, accounting restatements, and earnings management, and he is currently leading the research project (No. 71172186) funded by National Natural Science Foundation of China. E-mail: zhangjr@mail.xjtu.edu.cn

Rizwan Ali is a lecturer of finance at Lahore Business School, University of Lahore. He has enrolled as a PhD scholar at the same university. His research interest includes corporate finance, behavioral finance and investment. E-mail: rizwan.ali@lbs.uol.edu.pk

\section{REFERENCES}

1. Ammar, A. (2003). Indicator Variables model of firm's size-profitability relationship of electrical contractors using financial and economic data. Journal of Construction Engineering and Management, 129(2).

2. Chengwen, M. A., \& Wenhua, W. (2012). Performance evaluation on listed companies of electronic information industry in china based on panel data. International Journal of Innovative Management, 3.

3. Chan, K. C., Chen, Nai-fu, Hsieh and David A. (1985), “An Exploratory Investigation of the Firm Size Effect", Journal of Financial Economics, 14(3), 451-472.

4. Dong, X.-Y. (2006). Privatization and firm performance: A comparison between rural and urban enterprises in China. Journal of Comparative Economics, 34, 608-633.

5. Goddard, J., Tavakoli, M., \& Wilson, J. O. S. (2005). Determinants of profitability in European manufacturing and service: Evidence from dynamic panel model. Applied Financial Economics, 15, 12691282.

6. Hall, M., \& Weiss, L. (1967). Firms size and profitability. The Review of Economics and Statistics, August, 319-331.

7. Jonsson, B. (2007). Does the size matter? The relationship between size and profitability of Icelandic firms. Vinnugrein.

8. Majumdar, S. K. (1997). The impact of size and age on firm-level performance. Review of Industrial Organization 12, 231-241.

9. McNamara, R. (1995). Firm performance and macro-economic variables. (Discussion Paper 66). School of Business.

10. Memom, M. A., \& Tahir, T. M. (2012). Company operation performance using DEA and performance matrix: Evidence from Pakistan. International Journal of Business and Behavioral Sciences, 2(2).

11. Memom, M. A., \& Tahir, T. M. (2012). Performance analysis of manufacturing companies in Pakistan. Business Management Dynamics, 1(7), 12-21.

12. Mohd, B. A. (2009). The impact of macroeconomic variables on firm's performance: Evidence from Malaysian GLC MS Thesis.

13. Milost, F. (2003). Non-financial performance ratios as a management tool. Paper presented at the Proceedings of the 4th International Conference of the Faculty of Management Koper, University of Primorska. 
14. Naser, K. (2004). Determinants of corporate performance of Malaysian companies. Fourth Asia Pacific Interdisciplinary Research in Accounting Conference July 2004 Singapore.

15. Nil \& Cukur (2007). The effects of macroeconomic factors on the London stock returns. International Research Journal of Finance and Economics, 10.

16. Pratheepkanth, P. (2011). Capital structure and financial performance: Evidence from selected business companies in Colombo stock exchange Sri Lanka. Journal of Arts, Science \& Commerce, II(2), 171-181.

17. Ramasamy, B., Ong, D., \& Yeung, M. C. H. (2005). Firm size, ownership and performance in the Malaysian palm oil industry. Asian Academy of Management Journal of Accounting And Finance, 1, 81104.

18. Shaharudin, R. S. (2009). Does size really matter? A Study of size effect and macroeconomic factors in Malaysian stock returns. International Research Journal of Finance and Economics, 24.

19. Sankaran, K. (2002). Financial performance evaluation of pharmaceutical companies in India. Finance India, Delhi, 16(3), 1059-61.

20. Stekler, H. O., (1963). Profitability and size of firm. Institute of Business and Economic Research, University of California, Berkeley.

21. Stierwald, A. (2009). Determinants of firm profitability. Melbourne Institute of Applied Economic and Social Research.

22. Symeou, C. P. (n.d.). The firm size - performance relationship: an empirical examination of the role of the firm's growth potential. University of Cambridge.

23. Topak, M. (2011). The effect of board size on firm performance. Middle Eastern Finance and Economics, 14.

24. Velnampy, T., \& Nimalathasan, B. (2010). Firm size on profitability. Global Journal of Management and Business Research, 10(2). 